\title{
Unna's boot: experience of care of people with venous ulcers
}

\author{
Bota de Unna: vivência do cuidado por pessoas com úlcera varicosa \\ Bota de Unna: experiencia del cuidado de personas con úlcera varicosa
}

\section{Marcelo Henrique da Silva', Maria Cristina Pinto de Jesus', Deíse Moura de Oliveira', Miriam Aparecida Barbosa Merighi'}

' Universidade de São Paulo, School of Nursing, Postgraduate Program in Nursing. São Paulo, Brazil.

How to cite this article:

Silva MH, Jesus MCP, Oliveira DM, Merighi MAB. Unna's boot: experience of care of people with venous ulcers. Rev Bras Enferm [Internet]. 2017;70(2):349-56. DOI: http://dx.doi.org/10.1590/0034-7167-2016-0219

\section{Submission: 07-08-2016 Approval: 08-9-2016}

\begin{abstract}
Objective: to understand the experience of care of people with venous ulcers using an Unna's boot. Method: a qualitative study, based on the social phenomenology by Alfred Schütz, was carried out with 12 adults interviewed in 2015. The statements were analyzed and organized in thematic categories. Results: the following categories emerged: "Unna's boot annoyance versus wound improvement", "Difficulties for accessing care with the Unna's boot", "Care for healing and preventing recurrence", and "Receiving more attention from the healthcare professional". Conclusion: the experience of care of people using an Unna's boot revealed the annoyance caused by this device, which was overcome due to the wound improvement. However, access to care was compromised by the lack of structure at the service, frustrating the patients' expectations regarding wound healing. The issues of these people's intersubjective universe should be considered in the management of care of venous ulcers.
\end{abstract}

Descriptors: Varicose Ulcer; Compression Bandages; Self Care; Chronic Disease; Nursing.

\section{RESUMO}

Objetivo: compreender a vivência de cuidado de pessoas com úlcera varicosa em uso da Bota de Unna. Método: estudo qualitativo fundamentado na fenomenologia social de Alfred Schütz, realizado com 12 adultos entrevistados em 2015. Os depoimentos foram analisados e organizados em categorias temáticas. Resultados: foram desveladas as categorias: "O incômodo da bota de Unna versus a melhora da ferida", "Dificuldades para o acesso ao cuidado com a Bota de Unna", "Cuidar para cicatrizar e prevenir recidivas" e "Receber mais atenção do profissional de saúde". Conclusão: a vivência de cuidado de pessoas em uso da Bota de Unna revelou o incômodo proporcionado por este dispositivo, superado pela melhora da ferida. Porém, o acesso ao cuidado foi comprometido pela falta de estrutura do serviço, frustrando as expectativas dos participantes em relação à cicatrização da ferida. As questões do universo intersubjetivo dessas pessoas devem ser consideradas na gestão do cuidado da úlcera varicosa.

Descritores: Úlcera Varicosa; Bandagens Compressivas; Autocuidado; Doença Crônica; Enfermagem.

\section{RESUMEN}

Objetivo: comprender la experiencia del cuidado de personas con úlcera varicosa utilizando la Bota de Unna. Método: estudio cualitativo, fundamentado en fenomenología social de Alfred Schütz, realizado con 12 adultos entrevistados en 2015. Testimonios analizados y organizados en categorías temáticas. Resultados: surgieron las categorías: "Incomodidad de la Bota de Unna versus mejora de la herida", "Dificultades para el acceso al cuidado con la Bota de Unna", "Cuidar para cicatrizar y prevenir recidivas" y "Recibir más atención del profesional de salud". Conclusión: la experiencia de cuidado de personas utilizando la Bota de Unna expresó la incomodidad del dispositivo, superado por la mejora de la herida. No obstante, el acceso al cuidado resultó comprometido por falta de estructura del servicio, frustrando expectativas de los participantes respecto a la cicatrización de la herida. Las cuestiones del universo intersubjetivo de estas personas deben considerarse en la gestión del cuidado de la úlcera varicosa.

Descriptores: Úlcera Varicosa; Vendajes de Compresión; Autocuidado; Enfermedad Crónica; Enfermería. 


\section{INTRODUCTION}

Chronic venous ulcers (CVU), also called varicose ulcers, represent $70 \%$ of the vasculogenic ulcers, and they are estimated to affect $2 \%$ to $7 \%$ of the population worldwide, bringing, in addition to socioeconomic impact, great repercussion in the worsening of quality of life of the people who are affected by them ${ }^{(1)}$.

Care of CVU can be a challenge both for the people who live with them, and for the nurses who take care of them, due to their chronic and recurrent nature. A cohort study with 50 adult patients followed after CVU healing, during 10 years, showed that $62 \%$ had recurrence of the lesion. It evidenced that the use of compression stockings, rest, and the application of a moisturizing cream in the lower limbs (LL) had been considered efficient measures for the prevention of these recurrences ${ }^{(2)}$.

With this epidemiological scenario, there is a need to improve the care of these people, which should include the routine use of compression therapy (CT), and guidelines on basic hygiene care, feeding, rest and physical activity, aiming at healing and prevention of recurrence, and contributing to the improvement of the quality of life of people who live with this health problem ${ }^{(1,3)}$.

Compression therapy is the main care to be provided to this public, both to promote healing and to prevent recurrences ${ }^{(4)}$. It can be performed with the use of elastic compression, represented by short- or long-stretching bands, and by compression stockings. Another modality of compression is the inelastic CT, the effectiveness of which in the increase of the function of venous pumping, and reduction of the venous hypertension is recognized in the scientific environment ${ }^{(5)}$. In Brazil, Unna's boot is the most known and used inelastic CT in clinical practice ${ }^{(6)}$.

Studies show positive results regarding the use of Unna's boot for treating CVU concerning healing $\operatorname{rates}^{(7)}$, functional capacity ${ }^{(8)}$, self-esteem improvement ${ }^{(6)}$, and quality of life ${ }^{(3)}$. However, $\mathrm{CT}$ can be a challenge for the care of people with CVU, mainly regarding the continuity of its use, considering the adaptations that this therapy requires in people's daily lives ${ }^{(9)}$.

When care is seen as a confluence of subjectivities, the need for studies to explore the intersubjective nature present in this confluence is highlighted, and should be considered in the context of care of people who use an Unna's boot for treating CVU. Revealing these aspects can contribute to the reflection concerning the action of taking care guided by health professionals, mainly by nurses, who target the improvement of self-care practice to be carried out by the people who live with this chronic condition.

Therefore, the following questions guided the study: how do people using an Unna's boot live the experience of CVU care? What are the expectations these people have when using an Unna's boot for CVU care?

The objective of the study was to understand the experience of care of people with venous ulcers using an Unna's boot. Hence, by revealing the personal care grounded on professional care, the results of the present research are expected to direct mainly the nurse to a guided care that considers the existential context of people using an Unna's boot.

\section{METHOD}

\section{Ethical aspects}

Because this is a study involving human beings, the research project was approved by the Research Ethics Committee of EEUSP on September 18, 2015.

Type of study and theoretical and methodological framework

This is a qualitative study based on the Social Phenomenology by Alfred Schütz, which aims at the understanding of social phenomena based on the meaning that is attributed to the action by the actors involved in the social scene ${ }^{(10)}$. In this perspective, the adherence of this theoretical framework to the study regards the presupposition that health care originates from the interaction among people (intersubjectivity), and always has an intention (intentionality) ${ }^{(10)}$.

The first experiences of care occur in the world of life (social world), and are acquired with the family and close people. Throughout life, personal experiences, and the knowledge on healthcare transmitted by the professionals, are added to these experiences (collection of knowledge). The collection of knowledge and the position of the actors in the social sphere (biographical situation) allow the establishment of common goals for the social action ${ }^{(10)}$. According to the Social Phenomenology, care is socially constructed, and stems from the existential context, being stimulated by human motivation. Thus, action is a human behavior that is projected by the subject conscientiously and intentionally. It includes life projects (reasons for) and performed acts (reasons why) ${ }^{(10)}$.

\section{Research setting}

The research was developed at the Unna's Boot Service of the Institute of Specialized Clinics (ICE) of a city in the state of Minas Gerais. This service is linked to the dermatology and angiology service of this institute.

\section{Data source}

In order to have access to the potential participants, the researcher in charge - a doctoral student of Sciences - first contacted the chief nurse of ICE, who gave the preliminary information of the service, and the guidelines related to the bureaucratic proceedings for the authorization of the research in the Unna's Boot Service. Following authorization by the ICE and the nurse in charge for the sector, access was given to the list of patients in treatment for CVU. At that moment, forty people were enrolled, and were treating their venous ulcer with the inelastic compression therapy.

For the selection of the possible participants of the study, the following were considered as inclusion criteria: being an adult or older adult, being registered at the ICE, having a diagnosis of CVU, and using an Unna's boot for the care of the lesion. The statements whose content was not enough to meet the objectives of the study were excluded.

\section{Data collection}

Before initiating data collection, the researcher made five visits, one for each day of the week, to know the possible participants, and to establish a reliable relation and later make the invitation for the interview. The initial contact between the researcher 
in charge and the people being treated for CVU was mediated by the service's nurse or nurse technician. Informal conversations, and the care follow-up helped the possible interviewees to get to know the researcher in charge of data collection.

The statements were obtained by means of phenomenological interviewing, which aims at having access to the human being experience through the movement of comprehension. This is translated by the participants speech, when they describe the action experienced $^{(11)}$. By means of this modality of interview, the approach to the participants was sought, as well as the development of empathy for the obtainment of statements from people with CVU using an Unna's boot for wound treatment.

Before initiating the interviews, the people were instructed as for the objective of the research and importance of their participation, authorizing it formally by means of the signature of a free and informed consent form. Their permission was requested to use a recorder during the interviews, to allow the complete register of statements, and their later analysis.

The interviews were carried out in October and November of 2015, in days, times, and places defined by the people who agreed to participate in the study, so that they could feel at ease and safe to verbalize their experiences regarding the use of an Unna's boot. All participants opted to be interviewed at the ICE. The service made a privative room available so that the researcher could approach them. The average duration of each interview was 50 minutes.

To characterize the participants and to situate them biographically, personal, socioeconomic, and wound history data were included in the interview. The following questions guided the interview: How do you feel when taking care of the chronic venous ulcer with the use of the Unna's boot? What expectations do you have when using the Unna's boot for CVU care?

The collection of statements finished when the researcher realized that the questions were answered and the objectives of the research were reached. Theoretical saturation ${ }^{(12)}$ occurred in the ninth interview, with no evidence of new meanings until the twelfth statement. All the statements were included in the study, totaling 12 interviews. To ensure anonymity, the entries were identified by the letter I, as in interview, and an Arabic number corresponding to the order of the interviews: I1 to I12.

\section{Data organization and analysis}

The research material was organized and categorized according to the steps adopted by social phenomenology researchers ${ }^{(13)}$. Initially, thorough readings of each complete statement were carried out to identify and understand the meaning of CVU care with the use of an Unna's boot. Then, the non-structured material from the convergence of meanings concerning CVU care was organized, with the objective to obtain concrete categories, considered as objective constructs elaborated by the researcher, based on the experience explained by the participants. The results were discussed on the light of the Social Phenomenology by Alfred Schütz and other references related to the theme.

\section{RESULTS}

Five men and seven women participated in the study, with a mean age of 61 years, income of a minimum wage, and four years of study. Most of them were catholic, self-declared black, with mean time of 13 years with the lesion.

Understanding the experience of care of people with CVU using an Unna's boot included the social context that interferes with this care (reasons why), which was disclosed in the categories: "Unna's boot annoyance versus wound improvement" and "Difficulties for accessing care with the Unna's boot". It also included these people's intentionality when searching for the specialized service of Unna's boot (reasons for) expressed in the categories: "Care for healing and preventing recurrence", and "Receiving more attention from the healthcare professional".

\section{Category 1: "Unna's boot annoyance versus wound improvement".}

When taking care of CVU with the use of an Unna's boot, the participants mentioned the annoyance caused by the odor exhaled during the use of the device, the difficulty for body hygiene and deambulation, pain, and the constraint regarding the appearance of the legs:

The bad thing of the boot is that, at the beginning of the treatment, it produced very bad smell, it was necessary to change gauzes many times a day, but now it is reduced. (I6)

[...] the boot disturbs during bath. It is necessary to put a bag over the boot and the foot in a stool to firm the leg. (19)

I walk with difficulty with the boot, it is not possible to walk normally. [...] it presses and ties the leg completely. Sometimes, you are in a place and forget it, and put the leg out, then people see that thing on your leg (Unna's boot) and says: "Wow" (I10)

Despite the difficulties stated, the participants mentioned good results obtained with the use of the Unna's boot. They perceive the improvement of $\mathrm{CVU}$, when they compare this modality of treatment with others used previously:

[...] I am happy with the success of my treatment after I put the Unna's boot. I have never seen such a treatment. I have already used other dressings that were not useful, but the result of this boot is excellent, overcame the other treatments. (I2)

[...] I came to this service and started using the Unna's boot. With it, I feel that my treatment succeeded. I have already used alginate, hydrocolloid and ointments, but they did not solve the problem. (16)

Then I started using the Unna's boot as a recommendation of the angiologist. With it, I noticed that the wound reduced a lot. (I11)

\section{Category 2: Difficulties for accessing care with the Unna's boot}

Issues related to the health service and which make the care of CVU difficult were evidenced. Among them, there is the waiting list for entering the Unna's boot service, and the lack of material resources, along with the precarious structure of the net of services focused on these patients' assistance:

[...] Sometimes, there was a lack of boots. Then I bought it and brought to the nurse to put it not to interrupt my 
treatment. [...] we end up impairing the treatment if we don't buy it. It takes a long time, I was in the line for two years, waiting for a vacancy, and, since the health centers do not have the material, there are no conditions for the adequate treatment, then wound only gets worse. (I3)

There was a time when there was a lack of boots in the service, and it took a long time for them to arrive. I even bought one. In the retail, the price varies, there are boots of 40 to 50 reais and as we have to change it every week, it gets too expensive for us to follow the treatment buying the boot. (17)

It is difficult to make an appointment with the angiologist here, because there are many people in the line. The doctor asked me to come back in a month, but when I go to the health center they say that it takes a long time to schedule a return visit. (I12)

\section{Category 3: Care for healing and preventing recurrence}

A perspective of healing implies the care of CVU to suppress the pain caused by the presence of the wound, which would contribute for the improvement of the quality of sleep, as well as of the social relations now affected by the lesion:

If this wound healed, my life would be another, a life without pain. So, I expect that, with the aid of God and the orientation from doctors and nurses who take care of me, that this wound will heal. (I1)

I hope I can take care of the wound, and to stay the most time possible without opening the wound, without pain. Without the wound, life improves, our mood too, because we get nervous, with no patience with the pain of the wound. And this disturbs me a lot, even the relationship with my daughter, when I have pain, I get angry, with no patience with her. I live to take care of the wound, searching for doctors and nurses to help me. (I5)

I want to do everything I can to take care of the wound and to be healed. With the boot, it has already improved a lot, but I have already had nights awake because it hurts, I feel a stabbing inside. I want my leg to have no wound, no pain. (I11)

Healing as a consequence of care for CVU is seen as a possibility of social reinsertion. Social life was affected by the odor, modified appearance of the leg, difficult mobility, restriction in the use of certain footwear, clothes, and performance of work and leisure activities due to the presence of the wound and bandages:

[...] I want to take care to have it healed, because I notice that, sometimes, I arrive and sit in the bus seat, and people look at it, feel the smell and leave. We feel very isolated. (I1)

If my legs improved, I would feel more relieved, this disturbs me a lot, I want to wear a shoe on the foot but I can't; sometimes, I want to go out, but with the leg injured and swollen, I can't walk well, the dressing on the leg also disturbs me [...]. If it healed, I would be more at ease. Without the bandages on the leg, I could wear a shoe and move the leg, therefore I want to take care of my wound. (I4)
To get a job in a company, I can't, I can only take informal jobs, because companies don't accept me. When I take the admission examination, I can't hide this wound, I have to show it. (I2)

The chronic condition of the disease perceived by the participants makes them keep care after CVU healing, to prevent recurrences:

[...] This thing of having varices is for the rest of my life. I see that, in my family, my mother also had. [...] even if the varices don't heal, I want to stay the most time I can with no wounds. (15)

So, when the wound heals, I will have to take care of the nutritional part, to continue the rest, to use the bandage or the compressive stockings, to avoid hitting things, scratching the leg for the wound not to come back. (16)

[...] after healing, and after I stop using the boot, I will have to wear stockings for a long time. (I12)

\section{Category 4: Receiving more attention from the healthcare professional}

The statements reveal fragility in the relation with the healthcare professional, which can be a barrier for the care of CVU:

I wait for a treatment with a professional who gives me attention. I have already been in a health center where they did not even uncover my wound. They only put the hand on my foot and said that circulation was good. Then we don't believe on what they say. (I8)

[...] "you are good, the skin of the leg is excellent, the wound has a good color" and this is the only thing you hear. We feel like stopping treatment. If I am not feeling well with the treatment, I can complain! I also have my opinions. (I10)

[...] sometimes I have no desire to come here. I would like them to say "you will do this, you I can eat this, you can't eat that, you can't walk" or if I can walk. (I11)

\section{DISCUSSION}

The understanding of the experience of care of people with CVU using an Unna's boot leads to the assumption of social phenomenology that action is socially constructed, has its origin in the existential context, being stimulated by human motivation ${ }^{(10)}$. In the present investigation, the action in question - taking care of CVU with the use of an Unna's boot - revealed that the people on this therapy commonly come from a context that is marked by unsuccessful treatments. In this perspective, they are encouraged to use the Unna's boot as a possibility of wound healing and, for this purpose, they go to the health service in search of a professional who can instruct and pay attention to them (reasons for). The context of meanings (reasons why) discloses an experience of annoyance provided by the use of the Unna's Boot that is transposed when they notice the wound improvement. Moreover, the lack of structure of the specialized service is mentioned by the participants as a factor that delays wound recovery, and their expectations' achievement. 
The "reasons why" of the action in question initially translate the complaints of discomfort related to the odor, presence of the exudate, restrictions in mobility, body hygiene, and the constraint with the appearance of the legs. Brazilian studies corroborated these findings ${ }^{(14-15)}$. A phenomenological investigation that discussed self-care of CVU, from the perspective of adult and elderly women, showed that, due to the bandages, they had difficulties performing activities of daily living, such as carrying out their own body hygiene, and wearing clothes and footwear that needed to be adapted to meet the requirements of wound care ${ }^{(14)}$.

A qualitative study brought the experience of people affected by CVU, and highlighted the intense change in routine related to leisure. The difficulty to go out, travel and to take a walk also comes from the concern with the personal presentation, translated by the impossibility to wear clothes and shoes according to social standards ${ }^{(15)}$. These limitations imposed by the presence of the lesion should be considered by nurses, to keep CVU care, and can be changed in case people are well supported in wound care ${ }^{(14,16)}$. Thus, it is recommended that the person using an Unna's boot is heard, and instructed about self-care, with the discussion of strategies for coping with the problems they experience, to keep compliance with care.

In the present study, the participants noticed improvements in the evolution of CVU when they used the Unna's boot for treating the lesion, especially when compared to other modalities of treatment. A controlled and randomized clinical study carried out in the city of Rio de Janeiro, Brazil, with 18 participants, of whom nine were treated with elastic bandage and nine with Unna's boot, evidenced a better result in CVU in areas of more than $10 \mathrm{~cm}^{2}$, when treated with this device, and areas of less than $10 \mathrm{~cm}^{2}$ when treated with the elastic bandage associated with Petrolatum gauze ${ }^{(r)}$. The treatment with Unna's boot also led to a significant reduction of the exudate ${ }^{(7)}$.

A study performed in São Paulo, Brazil, corroborated the findings of the present research in what regards the duality expressed by the participants when reporting, at the same time, the annoyance caused by the use of Unna's boot and CVU improvement. In that study, although the participants initially showed serious difficulty or deficiency to perform activities of daily living, there was an improvement in the capacity to perform these activities after eight months of treatment with the Unna's boot ${ }^{(8)}$.

The participants of the present research reported difficulties that affect $\mathrm{CVU}$ care derived from the lack of structure in the institution destined to the treatment of wounds. Other Brazilian studies evidenced that, along with the difficulties related to the subjects themselves, related to CVU treatment, there is little support on the part of the health service for the treatment of these people. A lack of resources and protocols for care, and the need for specialized services of reference stood out ${ }^{(17-18)}$. However, we can point out that the availability and the use of materials that are adequate for dressings are directly associated with the quality of nursing care ${ }^{(17)}$.

The lack of Unna's boots, evidenced in the specialized service, and the limited number of vacancies and procedures make people wait a long time to initiate CVU care, which can influence negatively the time of recovery and life with the wound. Moreover, this has a financial onus for the people who often have to neglect other personal and family needs to buy the necessary material for wound care.

The context for the participants of the present research have a direct relation with their expectations regarding CVU care with the use of the Unna's boot. Thus, they see, in this treatment, the possibility of lesion healing (reasons for), glimpsing the restoration of their functional capacity and the daily activities affected due to the wound.

As for daily life with the wound, pain stands out as one of the issues that bother these people, with negative repercussions in their physical and mental well-being. Besides pain, other discomforts, such as the presence of exudate, odor, restriction in mobility, and sleep changes in people with CVU, contribute for the worsening of quality of life; this can also affect healing, when they are not well handled ${ }^{(15,19-21)}$. In this perspective, we can highlight that the reestablishment of skin integrity is also linked to a possible reinsertion in the labor market, which appears as an expectation of the participants of the present investigation. The restriction to work activities for the people with CVU was reported in the literature as a condition that can lead them to leave work, and request disability retirement. Moreover, the lesion brings economic repercussions, reflecting in their financial conditions ${ }^{(15,22)}$.

When facing the chronicity of the lesion, the participants reveal the desire to adopt continuous care, such as the use of CT, feeding, rest and general skin care, aiming at the prevention of recurrences after wound healing. CVU recurrence is very common, and in some cases, the ulcer can never heal completely, which can result in frustration for the professionals, and feelings of desperation for these people who developed chronic venous insufficiency ${ }^{(23)}$, resuming coping of challenges related to care and to the process of living with this chronic status ${ }^{(22)}$.

In the context of a chronic disease, care, in addition to being the responsibility of the patients themselves who live with the chronic condition, and of the family members, implies the co-responsibilization of professionals and health institutions, since this is a type of linear care that will have to be adopted by these people throughout life, with consequences on their future projects. This shared care presupposes dialogue, being a channel for the joint construction of the therapeutic plan, considering the priority chosen between the professional and the people with chronic diseases ${ }^{(24)}$.

A study carried out in the South region of Brazil highlighted the importance of the healthcare professional in the support to the care of people with $\mathrm{CVU}$, considering their chronic condition. Thus, this care is an action that is shared by the person affected by the wound and the health professional ${ }^{(15)}$.

It is believed that this care has to be structured in a network, making an effective coordination of actions and health services, and being coordinated by the Primary Health Care, which should take longitudinal care of the population living in the territory, despite being directed to other levels of complexity. In addition, the need for reorganizing the work process in the different points of health care of the Unified Health System (SUS) is reinforced. Therefore, the importance of embracement is emphasized, which should be performed by qualified professionals to listen to and to positively respond 
to the population health needs. Also important in this context is the need for strategic resources, which assist health professionals in the accomplishment of qualified care ${ }^{(25)}$.

In this context, the participants of this research expect the embracement of users' health needs, either in form of resources, or legitimated in the attentive position of the professional who takes care of these patients. People who live with CVU look for specialized services expecting that there they will be effectively taken care, which presupposes the knowledge of the general conditions of the user and of the lesion, and the degree of motivation for the treatment on the part of the professionals, to guide them more assertively on the necessary care for wound healing.

Thus, the performance of professionals, notably the nurse, is crucial so that people affected by a chronic disease are wellinformed about their health condition, and can feel motivated to cope with the disease and to comply with the proposed care. Moreover, instructions from health professionals may lead people with chronic diseases to recognize the signals of alert of their possible complications, as well as the ways to prevent them, minimizing disabilities related to the process of disease in question ${ }^{(24)}$.

Most of the time, people with chronic diseases mobilize knowledge independently to perform their own care, always in accordance with what they consider to be better for themselves ${ }^{(26)}$. That is, to take care of themselves, they use the knowledge sedimented from their own experience with the disease, and the care with family members who experienced the same condition (collection of knowledge) ${ }^{(10)}$. When this is not possible, they request instructions from formal and informal caregivers for performing this care $^{(26)}$. However, it is important to have in mind that people follow the advice of healthcare professionals when they understand these professionals, when they believe that it brings benefits and is attainable; thus, the adequacy of information to people's condition is important, so that it is understood and used in the care related to the chronic health situation ${ }^{(26)}$.

Therefore, the interpersonal relation between the health professional and the people affected by CVU translates the intersubjectivity established for the provision of care. According to the social phenomenology, daily life takes place in a cultural and intersubjective setting, and that is why people are both influenced and influence others, understanding and being understood in the relations they establish, considering their cultural and historical context ${ }^{(10)}$.

In this study, the participants evidenced fragilities in the established interpersonal relation between them and the health professional when they sought CVU care. A study developed in
Belgium showed that confidence in nurses and physicians was critical for leg ulcer treatment compliance. Providing attention, listening to, and advising patients provided their familiarization with the professionals, especially of those who had received little attention from other professionals who saw them ${ }^{(9)}$.

Thus, it is necessary that the relation between healthcare professionals and CVU patients using an Unna's boot is "face to face". Social phenomenology defends this relation as the strongest social relation, since participants are completely focused on each other ${ }^{(10)}$. Reaching this type of relation when negotiating care leads to the need for permanent education activities with healthcare professionals, in what regards the service delivered to the CVU patients ${ }^{(27)}$. The process of training in service therefore assumes crucial importance for the adequate approach, embracement, and care for users with CVU using an Unna's boot.

Care of CVU mediated by the use of the Unna's boot needs to take place along with a compatible structure for the action of care, as well as with the professionals involved in it - including nurses -, so that they are apt to share the care with the user, aiming at lesion healing, and maintenance of care by the person throughout life.

\section{CONCLUSION}

The experience of care of patients using an Unna's boot revealed the annoyance caused by this compression device, which was overcome after wound improvement. It showed that access to care was compromised by the lack of service structure, and that these people's expectations are directed to wound healing, to the prevention of recurrences, and to receiving more attention from healthcare professionals.

When understanding the experience of care of people with CVU using an Unna's boot, this study brings contributions for the management of health services, where nursing and other categories of professionals should act together in CVU care. Network care, equipped with the necessary resources and structure for the provision of effective answers to individuals' health needs should have priority in this context.

The fact that this study was carried out with a specific group, which uses the Unna's boot for CVU care in a certain specialized service, with individual characteristics, does not allow the generalization of its results. However, it presents relevant aspects concerning the singularity involved in the intersubjectivity of care, which should be considered by the professionals who take care of this population, especially wound enterostomal nurses.

\section{REFERENCES}

1. Souza EM, Yoshida WB, Melo VA, Aragão JA, Oliveira LA. Ulcer due to chronic venous disease: a sociodemographic study in northeastern Brazil. Ann Vasc Surg[Internet]. 2013 [cited 2016 Jul 05];27(5):571-6. Available from: http://dx.doi.org/10.1016/j. avsg.2012.07.021

2. Borges EL, Ferraz AF, Carvalho DV, Matos SS, Lima VLAN. Prevention of varicose ulcer relapse: a cohort study. Acta Paul Enferm[Internet]. 2016[cited 2016 Sep 12];29(1):9-16. Available from: http://www.scielo.br/pdf/ape/v29n1/en_1982-0194ape-29-01-0009.pdf 
3. Salomé GM, Ferreira LM. Quality of life in patients with venous ulcers treated with Unna's boot compressive therapy. Rev Bras Cir Plást[Internet]. 2012[cited 2016 Jul 06];27(3):466-71. Available from: http://dx.doi.org/10.1590/S1983-51752012000300024

4. O'Meara S, Cullum N, Nelson EA, Dumville JC. Compression for venous leg ulcers. Cochrane Database Syst Rev[Internet]. 2012[cited 2016 Jul 05];14(11):CD000265. Available from: http://onlinelibrary.wiley.com/doi/10.1002/14651858.CD000265.pub2/abstract;jses sionid $=$ 6EB3CDAA2A9C6521D6849BF95DB6CBE4.f04t02

5. Mosti G. Compression in leg ulcer treatment:in elastic compression. Phlebol[Internet]. 2014[cited 2016 Jul 05];29(1suppl):146-52. Available from: http://phl.sagepub.com/content/29/1_suppl/146.long

6. Salomé GM1, de Brito MJ, Ferreira LM. Impact of compression therapy using Unna's boot on the self-esteem of patients with venous leg ulcers. J Wound Care[Internet]. 2014 [cited 2016 Jul 06];23(9):442-6. Available from: http://dx.doi.org/10.12968/ jowc.2014.23.9.442

7. Abreu AM, Oliveira BGRB. A study of the Unna Boot compared with the elastic bandage in venous ulcers: a randomized clinical trial. Rev Latino-Am Enferm[Internet]. 2015[cited 2016 Jul 06];23(4):571-7. Available from: http://dx.doi.org/10.1590/0104-1169.0373.2590

8. Lima EL, Salomé GM, Brito Rocha MJ, Ferreira LM. The impact of compression therapy with Unna's boot on the functional status of VLU patients. J Wound Care[Internet]. 2013[cited 2016 Jul 06];22(10):558-61. Available from: http://dx.doi.org/10.12968/ jowc.2013.22.10.558

9. Van Hecke A, Verhaeghe S, Grypdonck M, Beele H, Defloor T. Processes underlying adherence to leg ulcer treatment: a qualitative field study. Int J Nurs Stud[Internet]. 2011[cited 2016 Jul 06];48(2):145-55. Available from: http://dx.doi.org/10.1016/j. ijnurstu.2010.07.001

10. Schütz A, Luckmann T. Las estructuras del mundo de la vida. Buenos Aires: Amorrortu; 2009.

11. Paula CC, Padoin SMM, Terra MG, Souza IEO, Cabral IV. Modos de condução da entrevista em pesquisa fenomenológica: relato de experiência. Rev Bras Enferm[Internet]. 2014[cited 2016 Jul 06];67(3):468-72. Available from: http://dx.doi. org/10.5935/0034-7167.20140063

12. Fontanella BJB, Luchesi BM, Saidel MGB, Ricas J, Turato EB, Melo DG. Amostragem em pesquisas qualitativas: proposta de procedimentos para constatar saturação teórica. Cad Saúde Pública[Internet]. 2011[cited 2016 Jul 07];27(2):388-94. Available from: http://www.scielo.br/ $\mathrm{pdf} / \mathrm{csp} / \mathrm{v} 27 \mathrm{n} 2 / 20 . \mathrm{pdf}$

13. Jesus MCP, Capalbo C, Merighi MAB, Oliveira DM, Tocantins FR, Rodrigues BMRD et al. The social phenomenology of Alfred Schütz and its contribution for nursing. Rev Esc Enferm USP[Internet]. 2013[cited 2016 Jul 07];47(3):736-41. Available from: http://www.scielo.br/pdf/reeusp/v47n3/en_0080-6234-reeusp-47-3-00736.pdf

14. Silva MHS, Jesus MCP, Merighi MAB, Oliveira DM. A experiência de autocuidado de mulheres que convivem com úlcera venosa crônica. Estima[Internet]. 2016[cited 2016 Jul 07] 14(2):61-7. Available from: http://www.revistaestima.com.br/index.php/estima/article/view/378

15. Silva DC, Budó MLD, Schimith MD, Ecco L, Costa IKF, Torres GV. Experiences constructed in the process of living with a venous ulcer Cogitare Enferm[Internet]. 2015[cited 2016 Jul 07];20(1):13-9. Available from: http://revistas.ufpr.br/cogitare/article/view/37784/24830

16. Jones JE, Robinson J, Barr W, Carlisle C. Impact of exudate and odor from chronic venous leg ulceration. Nurs Stand[Internet]. 2008[cited 2016 Jul 07];22(45):53-4. Available from: http://journals.rcni.com/doi/pdfplus/10.7748/ns2008.07.22.45.53.c6592

17. Sehnem GD, Busanello ], Silva FM, Poll MA, Borges TAP, Rocha EM. [Difficulties faced by nurses in nursing care for individuals with wounds]. Ciênc Cuid Saúde[Internet]. 2015[cited 2016 Jul 07];14(1):839-46. Available from: http://periodicos.uem.br/ojs/ index.php/CiencCuidSaude/article/view/20949 Portuguese.

18. Silva MH, Jesus MCP, Merighi MAB, Oliveira DM. Limits and possibilities experienced by nurses in the treatment of women with chronic venous ulcers. Rev Esc Enferm USP[Internet]. 2014[cited 2016 Jul 07];48(spe):53-8. Available from: http://www.scielo.br/pdf/reeusp/ v48nspe/0080-6234-reeusp-48-esp-054.pdf

19. Brtan Romić R, Brtan A, Romić I, Cvitanović H, Duvančić T, Lugović-Mi. Quality of life and perception of disease in patients with chronic leg ulcer. Acta Clin Croat[Internet]. 2015[cited 2016 Jul 07];54(3):309-14. Available from: http://www.ncbi.nlm.nih.gov/ pubmed/26666100

20. Edwards H, Finlayson K, Skerman H, Alexander K, Miaskowski C, Aouizerat B et al. Identification of symptom clusters in patients with chronic venous leg ulcers. J Pain Symptom Manag[Internet]. 2014[cited 2016 Jul 05];47(5):867-75. Available from: http://dx.doi. org/10.1016/j.jpainsymman.2013.06.003

21. Hellström A, Nilsson C, Nilsson A, Fagerström C. Leg ulcers in older people: a national study addressing variation in diagnosis, pain and sleep disturbance. BMC Geriatr[Internet]. 2016[cited 2016 Jul 06];16:25. Available from: http://bmcgeria tr.biomedcentral.com/articles/10.1186/s12877-016-0198-1

22. Aguiar ACSA, Amaral L, Reis LA, Barbosa TSM, Climene LC, Alves MR. Alterações ocorridas no cotidiano de pessoas acometidas pela úlcera venosa: contribuições à Enfermagem. Rev Cuban Enferm[Internet]. 2015[cited 2016 Jul 07];30(3). Available from: http://www.revenfermeria.sld.cu/index.php/enf/article/view/510/98

23. Brown A. Life-style advice and self-care strategies for venous leg ulcer patients: what is the evidence? J Wound Care[Internet]. 2012[cited 2016 Jul 07];21(7):342-50. Available from: http://dx.doi.org/10.12968/jowc.2012.21.7.342

24. Brasil. Ministério da Saúde. Secretaria de Atenção à Saúde. Departamento de Atenção Básica. Caderno de Atenção Básica n. 35: Estratégias 
para o cuidado das pessoas com doença crônica[Internet]. Brasília: Ministério da Saúde, 2014[cited 2016 Jul 06]. 162 p. Available from: http://bvsms.saude.gov.br/bvs/publicacoes/estrategias_cuidado pessoa doenca cronica_cab35.pdf

25. Malta DC, Merhy EE. O percurso da linha do cuidado sob a perspectiva das doenças crônicas não transmissíveis. Interface Comunic Saúde Educ[Internet]. 2010[cited 2016 Jul 07];14(34):593-606. Available from: http://www.scielo.br/pdf/icse/v14n34/ aop0510.pdf

26. Novais E, Conceição AP, Domingos ], Duque V. O saber das pessoas com doença crônica no autocuidado. Rev HCPA[Internet]. 2009[cited 2016 Jul 07];29(1):36-44. Available from: http://seer.ufrgs.br/index.php/hcpa/article/view/7376/4964

27. Santana AC, Bachion MM, Malaquias SG, Vieira F, Carneiro DA, Lima JR. Caracterização de profissionais de enfermagem que atendem pessoas com úlceras vasculares na rede ambulatorial. Rev Bras Enferm[Internet]. 2013[cited 2016 Jul 07];66(6):821-26. Available from: http://dx.doi.org/10.1590/S0034-71672013000600002 